ISSN 1916-7822. A Journal of Spread Corporation

Volume 10. No. 22021 Pages 1-16

\title{
Teacher's Use of Instructional Materials in Teaching and Learning Mathematics in Rwandan Primary Schools
}

\section{Clementine Umuhoza \& Alphonse Uworwabayeho}

University of Rwanda-College of Education

Rwanda

\begin{abstract}
Teaching and learning mathematics is easier, more interesting, more enjoyable, and more closely connected to real life applications with the use of instructional materials like textbooks, manipulatives, technology tools, and (physical or digital) models. This study investigated the impact of instructional aids on classroom interaction through semi-structured interviews and classroom observations of 15 mathematics teachers from five primary schools in Rulindo district, in Rwanda's Northern Province. Interviews were analyzed thematically, and classroom observations were analyzed descriptively. The analysis indicates a lack of instructional materials for teaching mathematics overall. Most teachers use course books, but report that there are not enough books available. Use of ICT is limited due to the lack of power supply in some schools. Teachers in this study either did not use available instructional materials at all, or, if they were used, they were not used appropriately. Teachers also did not allow students to actively use the materials; thus, students were not given the opportunity to enhance their active learning and participate in constructing their knowledge of the mathematics content.
\end{abstract}

Keywords; mathematics, primary schools, teaching and learning, use of instructional materials

\section{Introduction}

Instructional materials are also known as teaching aids which are used by teachers during teaching practice, to demonstrate and explain procedures, concepts, and phenomena under study (Ng'etich \& Chemwei, 2015). Instructional materials are any kind of aids that assists in the teaching and learning activities, including reference books, counting equipment like blocks, stones or beads, natural displays models, charts, pictures, play materials, games, and audiovisual equipment (Cartledge \& Milburn, 1986; Goldstein, 1994). According to Kadzera (2006), instructional materials are those tools that stimulate students to learn, as well as provide 
teachers with the facility of explaining new mathematical concepts in meaningful ways. The use of instructional materials is found to be a powerful strategy for effective teaching and learning mathematics (Adebule \& Ayoola, 2016). The use of instructional materials in mathematics enhances students' academic achievement in mathematics (Agwagah, 2001; Bala \& Musa, 2006).

Mathematics is an essential subject among the curriculum subjects taught at schools (Alshatri et al., 2019). The relevance of mathematics in national development, human activities, scientific and technological careers as well as in numerous careers is attested in the literature (Bala \& Musa, 2006; Eraikhuemen, 2003; Kalyan, 2020). However, because of the abstract nature of mathematics, students have difficulties understanding this subject (Mabagala, 2019). Therefore, it is important to identify ways of making mathematics more concrete for learners so they can understand it more easily. Instructional materials, such as those listed above, provide an important means of doing so.

Rwanda is currently its Vision 2030 program that encompasses Sustainable Development Goals Four (SDG4), with a focus on quality education that calls for ensuring inclusiveness, equitable education, and promoting lifelong learning opportunities for all (Henao, Hui, \& Gordon, 2017). Rwanda's current competency-based curriculum (CBC) emphasises on developing students' skills and competencies and a central approach is interaction with the available instructional materials (Rwanda Education Board [REB], 2015). Primary education in Rwanda usually starts at the age of 7 years and lasts for six years ( REB, 2015). Integrating instructional materials into the curriculum is a key strategy to improving tecahing and learning quality at primary level. It is understood that children learn better by seeing and doing. Instructional materials serve as teaching and learning aids that help students to learn effectively to increase their performance (Nyirahabimana, 2019). The use of instructional materials in teaching and learning mathematics makes learning easier, more interesting, concrete, enjoyable, and clear in real-life contexts.

Many students report finding mathematics difficult, and researchers recommend using concrete teaching aids (Mabagala, 2019). Students are likely to quickly forget what they hear, but remember what they have seen, touched, and interacted with (Olayinka, 2016). Despite the effectiveness of the use of instructional materials, it was observed that some schools lack basic instructional facilities and materials for the teaching and learning processes (Amadi, 2019). The study conducted by Nizeyimana and Nkiliye (2021) on the hindrances to quality of basic education in Rwanda, showed that there is a lack of instructional materials in Rwanda 
secondary schools, and this was considered to be one of the barriers to quality education in Rwanda. Indeed, when a curriculum is developed without adequate support, sufficient materials, and competent teachers, there is a waste on implementation of the curriculum (Ottevanger, 2001).

Despite the importance of instructional materials for primary mathematics teaching and learning, no study to date has investigated primary teachers' use of instructional materials during teaching and learning mathematics, and the impact of instructional materials on learner participation and understanding in Rwanda. Thus, the present study sought to answer the following question: How do primary teachers use instructional materials, in enhancing primary students' deep understanding of mathematics in Rwanda? The study points to the benefits of using instructional materials for primary mathematics teaching and learning in ways which support the implementation of competence-based curriculum (CBC) and improves learning outcomes.

\section{Review of the Related Literature and the guiding theory}

Both teachers and students need instructional materials for the successful teaching and learning of any subject (Janovsky, 2015). Within this vein, Msafiri (2017) argues that instructional materials help teachers to easily achieve instructional objectives and students to understand the content in practical ways. Ogbu (2015) observed that a teacher that uses teaching aids to deliver his or her lesson, will cover more facts in less time than one who rely on only oral lesson delivery. Brudett and Smith (2003) in their study based on 57 schools in England and Wales, concluded that the learning institutions with abundant learning and teaching resources perform better than the institutions without. Unfortunately, instructional materials are not sufficient in many schools in Rwanda, resulting in poor quality education. (Nizeyimana and Nkiliye, 2021)

In most cases, many learners have difficulties in understanding certain mathematical concepts as a result of their beginner level of cognitive operation. However, where standard instructional materials are scarce or unavailable in a school, those 'improvised' from locally available materials can enhance lessons (Ndihokubwayo et al., 2020). Onasanya et al. (2008) noted that improvisation demands venture, creativeness, curiosity, and determination on the part of teachers. Iji (2014) suggests that improvised instructional materials may enable students to build accuracy, understanding, and efficiency. Abimbade (2004) noted that the approach of using improvised materials in a mathematics classroom assists in the proper introduction of new skills, develops understanding, as well as shows the appropriate way of doing things. Egbu 
(2012) also argues that involving learners in classroom activities is critical as it makes teaching learner-centered. That is why educators should emphasis the use of instructional materials to guarantee a sustainable educational system(Ng'etich and Chemwei 2015).

On the other extreme, Umugiraneza et al., (2018) found that teachers in Kwazulu Natal schools, South Africa, do not use instructional technology in mathematics lessons because they were not confident enough in the preparation and use of the tools. The researchers also found that students were not familiar with these technology tools. Ogbondah (2008) suggested that what discourages the utilization of instructional materials is the lack of information on where tools can be found, lack of basic skills for teachers about the design, selection, and utilization of these tools, and non-availability of electricity. But all agree that studying with instructional support enhances students' understanding of self-regulated learning of mathematics (Agwagah, 2001; Bala \& Musa, 2006; Meyer \& Turner, 2002).

The present study is based on constructivist learning theory rooted in famous ideas of Jean Piaget, John Dewey, Jerome Bruner that learning occurs when learners are actively involved in the process of learning and when they construct their knowledge as opposed to passive learning that is concerned about students receiving information ) (Aljohani, 2017). The constructivist learning theory argues for keeping students actively involved in building and making their knowledge (Elliott, Kratochwill, Littlefield \& Travers, 2000). Research by Meyer \& Turner (, 2002). also indicate that information that students gain and retain in longterm memory is what they gained through learning by doing.

\section{Methodology}

This study employed a qualitative study design using a case study approach (Creswell, 2014). The researcher conducted the study in 5 public primary schools in Rulindo district in Northern Province of Rwanda. This is a region of mining where the majority of people are involved in the exploitation of minerals and was chosen because it is accessible to the researcher; hence, easier to collect data within a limited time frame.

The researcher randomly 5 schools from 90 primary schools At each school, three mathematics teachers were randomly selected. Therefore, 15 mathematics teachers were purposively sampled to participate in the study. All the selected teachers participated in the study willingly and there were no incentives for the participants. The sampled teachers' teaching experience ranges from four to twenty years. 
The study used two self-constructed types of data collection instruments, semistructured interview and classroom observation checklist. The development of these two instruments was guided by Piaget's theory that focuses on how learners interact with their environment to develop complex reasoning and knowledge (Kalina, 2009). The observation checklist was made of eight statements whereby the researcher has to record the "yes" or "no" options for each statement as a teacher is being observed. Both instruments were used because a combination of instruments helped the researcher to supplement the information provided during interview (Kothari, 2004). Interpretive research uses open ended interviews and observations to collect qualitative data which are mostly verbal instead of statistical data (Gall et al., 2003). In primary schools, a lesson lasts 40 minutes, which means that each teacher was observed for 40 minutes, equivalent to one period. During the observations, the researcher used an observation protocol containing the list of instructional materials that are found in the class and to what extent these instruments are exploited by both teachers and students during a mathematics lesson.

To carry out this study, the researcher obtained a license from the University of Rwanda to collect information after declaring that the information collected will be confidential and will be used for the present study only. This allowed the researcher to enter the sampled primary schools. Before an interview, the researcher explained the aim of the research to headmasters, and teachers were allowed to ask questions. Teachers were given consent forms to sign, and they were reassured that they can withdraw at any time without penalty. Teachers participated freely and voluntarily. Respondents were encouraged not to reference their names on the questionnaire, to ensure anonymity. Interview with teachers was done individually in a place of trust and confidentiality. The researcher assured respondents that they will be informed of the search results. All information and collected data were kept in a safe place.

Data collected from the interview were analyzed thematically. This analysis was employed through a process of coding, categorizing, and interpreting (McMillan \& Schumacher, 2010). Data from classroom observation were analyzed descriptively. This analysis was about counting the "yes" or "no" options recorded for each statement that is on the observation checklist and record their frequencies after observing all teachers. Both analyses were conducted to answer our research question related to what extent primary teachers use instructional materials within the Rulindo district, in enhancing primary students' understanding of mathematics. 


\section{Data presentation and discussion}

\section{Availability of instructional materials}

We started the interview by asking teachers whether they use instructional materials. All the interviewed teachers said that they use instructional materials, but they revealed that these instructional materials are not enough in their schools. The common instructional materials reported by the interviewed teachers are books, stones, jugs, manila papers, cords, meter ruler, cards, scales, dice, bottle tops, sticks, solids, coins, and abacus.

All teachers (15 out of 15$)$ reported that books are the most available instructional materials, although they said that these books are not sufficient (See Table 1). For instance, teacher T11 said: "Books are the most available instructional materials, but we do not have enough books compared to the number of students we have in a class". Some teachers reported that the scarcity of books prevents students to take books at home for self-study purposes. For instance, teacher T2 said: "The materials we use the most are color cards and books. But books are very few because each student cannot get a book to take at home to get help from parents". Only one teacher said that books are the most available materials. The respondent stressed that every student has a book that he or she can use at home for self-study. This is as it should be since students do not only need to use books while they are at school, but also while at home when they could be assisted by family members (Ukobizaba et al., 2019). Like other subjects, mathematics requires students to do exercises at home that the teacher could not cover in class. Good textbooks contain well prepared content that students who need to master the content can use. As constructivist learning theory stipulates, learners can actively keep building their knowledge when they are equipped with instructional materials (Elliott, Kratochwill, Littlefield \& Travers, 2000).

A main finding was teachers not having enough books for each student as indicated by $100 \%$ response to the question. The follow-ups on whether students use and exploit these books is also very important. Table 1 shows the number of teachers who have enough books and those who do not. The number of students per book is expressed in percentages. We concluded that books are enough when we found a percentage not lower than $50 \%$ or a ratio of $1 / 2$, i.e., where two students can share at least one book (See Table 1). 
Teacher's Use of Instructional Materials in Teaching and Learning Mathematics in Rwandan Primary Schools

Table 1. Books distribution per students in percentages

\begin{tabular}{lllll}
\hline Teachers & Number of books & Number of students & Ratio $(\%)$ & Observation \\
\hline T1 & 10 & 50 & 20 & Not enough \\
\hline T2 & 20 & 60 & 33.3 & Not enough \\
\hline T3 & 6 & 61 & 9.8 & Not enough \\
\hline T4 & 2 & 55 & 3.6 & Not enough \\
\hline T5 & 30 & 53 & 56.6 & Quite enough \\
\hline T6 & 40 & 50 & 80 & Enough \\
\hline T7 & 6 & 50 & 12 & Not enough \\
\hline T8 & 32 & 64 & 50 & Quite enough \\
\hline T9 & 4 & 65 & 6.1 & Not enough \\
\hline T10 & 5 & 52 & 9.6 & Not enough \\
\hline T11 & 4 & 66 & 6 & Not enough \\
\hline T12 & 20 & 58 & 34.4 & Not enough \\
\hline T13 & 6 & 49 & 12.2 & Not enough \\
\hline T14 & 21 & 60 & 35 & Not enough \\
\hline T15 & 19 & 54 & Not enough \\
\hline
\end{tabular}

In 15 teachers observed, only three have enough sufficient books. This is equivalent to20\% teachers who have enough books. This means that the remaining teachers (80\%) do not have enough books to be used while teaching mathematics.

\section{The use of instructional materials}

We asked how teachers use the available instructional materials. The majority of teachers (10 out of 15) said that they put students in groups to share few available books. For instance, T4 said:

We have books, but for a student to have access to a personal book is not easy. It requires us to put students in groups. Unfortunately, due to this pandemic coronavirus19, putting students in groups is not encouraged.

Explaining their use of other teaching materials apart from books, Teacher T6 said: 
I use various instructional materials differently. For instance, when I am teaching to count, I bring stones, beans, bottle tops, that students can count. When I am teaching about liquid container capacities, I bring jags, Iliter bottles. When I am teaching length measurement, I use cords and a one-meter ruler.

Teacher's pedagogy influences the use of instructional materials since it is through this pedagogy that a teacher will be able to select appropriate materials to be used depending on the content. As it is shown in Table 1, only 4 out of 15 teachers used the available teaching materials effectively. By effective use of instructional materials, it is implied that the material that can be seen clearly by every student, the teacher is seen explaining to students why, how, where, and when it will be used, and allows students to interact and use it themselves guided by the teacher. The teacher's knowledge about the use of instruments is very important because a teacher can use efficient materials poorly, using bad materials effectively as well as having poor and bad materials and use them poorly (Ahmed et al., 2004). It is therefore important to effectively implement the curriculum by using appropriate concrete materials for helping learners to gain experience, construct abstract ideas, make inventions, and build self-confidence (Cartledge \& Milburn, 1986).

\section{Information, communication, and Technology (ICT) tool use in primary schools}

Among the interviewed teachers, none agreed that he/she has ever used audio-visual aids. The teachers reported that these tools are not available. Teachers revealed that they do not have either a computer, a speaker, or a projector. In addition, $40 \%$ of the schools represented in the survey do not have electricity. This is problematic in a technological evolving world whereby ICT is being integrated into teaching and learning to facilitate instructions. The availability of electricity within schools is a basic infrastructure for teachers to be able to integrate ICT into teaching and learning Ogbondah (2008) reported that one of the problems related to instructional use is the lack of power supply. However, it has been noticed that Information Communication Technology (ICT) is currently contributing to enhancing education mainly in teaching and learning of Science, Technology, Engineering, and Mathematics (STEM) subjects (Ndihokubwayo et al., 2020). Teaching with tools such as digital imaging has the potential of bringing to the students a real-world contexts within which to learn(Ahmed et al., 2004)ICT tools like YouTube, for instance, can help students to conceptually understand various concepts in physics as well as in mathematics (Ndihokubwayo et al., 2020). 


\section{Improvisation of the instructional materials}

The teachers reported that the tools that they have at their schools are either provided by Rwanda Education Board (REB) and/or Building Learning Foundation (BLF). However, some teachers (8 out of 15) said that students can bring the materials from home or students' surroundings. Some teachers (5 out of 15) reported that students bring beans from home, especially when they are going to learn to count. Furthermore, teachers said that they improvise by making their instructional materials with students. For instance, one teacher named T12 said: "We make ourselves materials, and we ask kids to bring bottles tops, bottles, and stones." during the interview teachers said that they improvise, however, the classroom observation showed that they do not. However, improvisation requires the venture, creativity, curiosity, and commitment of teachers (Onasanya et al., 2008). This is why, although teachers may have an idea about the improvisation, the school authorities would need to encourage the teachers to improvise, given that some materials are expensive and/or difficult to find (Ndihokubwayo \& Habiyaremye, 2018). Abimbade (2004) also revealed that using improvised materials in a mathematics classroom assist in proper assimilation of new skills and develop students' understanding of how things are done.

The fact that some teachers in collaboration with students improvise by making their own instructional materials is advantageous not only for teachers, but also for students since it enhances students' ability of creativity and innovation. In addition, as long as teachers improvise the teaching materials, the budget that would be spent on conventional teaching materials is reduced and used for important expenses.

\section{Teachers' knowledge of using instructional materials}

Among the five observed classrooms, only two classrooms were equipped with instructional materials such as books, jugs, manila papers, cords, meter ruler, cards, scales, dice, bottle tops, sticks, and solids. The Table 1 shows the observed results about to what extent teachers use instructional materials.

\section{Table 2. Utilization of instructional materials}

\begin{tabular}{|l|l|l|l|}
\hline SN & Statements check list & Yes & No \\
\hline 1 & Are there any instructional materials in the classroom & $2 / 15$ & $13 / 15$ \\
\hline 2 & In class, there are concrete instructional materials? & $3 / 15$ & $12 / 15$ \\
\hline 3 & Are printed instructional materials available in the classroom? & $8 / 15$ & $7 / 15$ \\
\hline
\end{tabular}




\begin{tabular}{|l|l|l|l|}
\hline 4 & Are the instructional materials adequate and appropriate for the learners? & $0 / 15$ & $15 / 15$ \\
\hline 5 & Does the teacher use instructional materials during lesson delivery? & $5 / 15$ & $10 / 15$ \\
\hline 6 & $\begin{array}{l}\text { Does the teacher give learners time to interact with the instructional } \\
\text { materials during the lesson? }\end{array}$ & $5 / 15$ & $10 / 15$ \\
\hline 7 & Are there any audio-visual materials in the classroom? & $0 / 15$ & $15 / 15$ \\
\hline 8 & $\begin{array}{l}\text { Were the available instructional materials used effectively? } \\
\text { (Bringing the material that can be seen clearly by every student, explaining } \\
\text { to students why, how, where, and when it will be used, allowing students } \\
\text { to interact and use it themselves guided by the teacher) }\end{array}$ & $4 / 15$ & $11 / 15$ \\
\hline
\end{tabular}

During our classroom observation, the majority of classrooms (8 out of 15) were equipped only with printed instructional materials like books. We found that the other few instructional materials used by the teachers are not adequate (Amadi, 2019). We, therefore concur with Nizeyimana and Nkiliye (2021) who also found that most schools in Rwanda do not have enough instructional materials. It was also found that even when the instructional materials are available in class, the majority of teachers (10 out 15) do not use them. Time constraints on lessons and large class sizes were declared by teachers during the interview as factors that prevent the use of instructional materials. Adaylarinin et al. (2017) also found that teachers do not use instructional materials because of lack of knowledge and negative attitudes towards their use, difficulties of classroom management, financial constraints, and teachers' difficulties in preparing and using instructional materials.

It was observed that the majority of participant teachers (10 out of 15) do not give time to students to interact with available instructional materials. Only a few teachers (5 out of 10) were observed allowing students to interact with the materials. When learners interact effectively with instructional materials, they develop their psycho-motor skills. (Kalina, 2009) Students perform better in general in mathematics when they are given chance to interact or participate actively in the teaching-learning process when instructional materials are used (Adebule \& Ayoola, 2016). Students successfully perform hands-on activities that help them to become more creative.

Learning is supposed to take place when there is an acquisition of new behavior that takes place through classical and operative conditioningwhereby students respond to the stimuli and learning is boosted by direct manipulation of objects (Liao, 2012). Consequently, 
the lack of the needed instructional materials and resources leads students to remain passive during the teaching and learning process (Okobia, 2011). Using improvised materials in mathematics classrooms will be an effective way to inculcate students with new skills, understanding, and creativity (Abimbade, 2004). This will make learners to be actively involved in the process of knowledge construction as opposed to passive acquisition of knowledge (Aljohani, 2017). Giving students the opportunities to interact with the instructional materials will give them insights into the relevance of the tools being used. This will enable students to link what they learn with the real-life situation.

\section{Conclusion}

The present study investigated how primary teachers use instructional materials while teaching mathematics within the Rulindo district, in Rwanda. The results showed that the majority of mathematics classrooms are not equipped with sufficient instructional materials. The teachers reported that books are the most available instructional materials, however, teachers claimed that the available books are few. Teaching mathematics using instructional materials was found advantageous for both teachers and students since their use facilitates learning; the content is covered easily and quickly, and students understand mathematical concepts effectively. The majority of participant teachers did not use instructional materials and when they do, they did not allow students to interact with those materials. This pedagogy leaves students learning passively, since the students are not given chance to participate actively in constructing their knowledge.

Though the study was conducted at small scale, its findings suggest that Rwandan school leaders, teacher training institutions and other educational stakeholders should include improvisation and effective use of instructional materials in their agenda. This study provides pointers to what future studies could still do First, this small-scale study was conducted in only one part of the country. Thus, further studies can look at other districts for the purpose of generalization. Second, the present study was limited to exploring how instructional materials are being used in teaching mathematics in primary schools. Further studies can investigate the link between the use of instructional materials and students' performance of mathematics at the secondary school level in Rwanda.

\section{Acknowledgement}

We acknowledge Ms. Rachel [second name] from England, for evaluating this study and providing us with constructive criticisms. We also recognize Mr. Ukobizaba Fidele for his very useful comments. 
This study was financed by the African Centre of Excellence for Innovative Teaching and Learning of Mathematics and Science (ACEITLMS) of the University of Rwanda-College of Education (UR-CE).

\section{References}

Abimbade, C. (2004). Effective primary school science teaching, meaning, scope and strategies in T. O. Oyetunde, Y. A. Mallam and G. A. Andzagi (ed). The practice of teaching perspective and strategies pp 179-186. Jos: LECAPE Publishers.

Adaylarinin, R., Derslerinde, M., \& Kullanimina, R. M. (2017). Pre-service Mathematics Teachers about Using Instructional Materials in Mathematics Lesson. Journal of Theory and Practice in Education, 13(1), 10-34.

Adebule, S., \& Ayoola, O. (2016). Impact of Instructional Materials on Students' Academic Performance in Mathematics in Secondary Schools in Ekiti State, Nigeria. Research Journal of Educational Studies and Review, 2(1), 1-4.

Agwagah, U. N. V. (2001). Teaching Number Bases in Junior Secondary School Mathematics: The Use of the Base Board. Journal of the Mathematical Association of Nigeria, 26(1), 1-71.

Ahmed, A., Jeavons, A. C., \& Oldknow, A. (2004). How Can Teaching Aids Improve the Quality of Mathematics Education? Educational Studies in Mathematics, 56(2-3), 313328. https://doi.org/10.1023/B

Aljohani, M. (2017). Principles of "Constructivism" in Foreign Language Teaching. Journal of Literature and Arts Studies, 7(1), 97-107. https://doi.org/10.17265/2159$5836 / 2017.01 .013$

Alshatri, S. H., Wakil, K., Jamal, K. \& Bakhtyar, R. (2019). Teaching aids effectiveness in learning mathematics. International Journal of Educational Research Review, 4(3), 448453.

Amadi, E., \& Ezeugo, C. R. (2019). Physical Resources Availability and the Academic Performance of Students in the Universal Basic Education Scheme, Rivers State. International Journal of Innovative Development and Policy Studies, 7(1), 13-23.

Bala, A., \& Musa, B. (2006). Effect of the use of Number Base Game on Senior Secondary School Achievement in Number Bases. Journal of the Mathematical Association of 
Nigeria, 31(1), 103-114.

Brudett, M. \&, \& Smith, R. (2003). Leadership in Education London. Sage Publishers.

Cartledge, G. \& Milburn, J. (1986). Teaching Social Skills to Young Children: Innovative Approaches. Pergamon Press.

Creswell, W. J. (2014). Research Design: Qualitative, Quantitative and Mixed Methods Approaches (4 th Edition). SAGE.

Egbu, N. C. (2012). Approach to Teaching Methodologies. Bolton Publishers Ltd.

Elliott, S. N., Kratochwill, T. R., Littlefield, C. J. \& Travers, J. (2000). Educational psychology: Effective teaching, effective learning (3rd ed.). McGraw-Hill Publishing Company

Eraikhuemen, L. (2003). The Influence of Gender and School Location on Students' Academic Achievement in Senior Secondary School Mathematics. Journal of Theory and Research in Education, 7(2), 99-119.

Gall, M. D., Gall, J. P., \& Borg, W. R. (2003). Educational Research: An Introduction (7th Editio). Pearson.

Goldstein, J. (1994). Toys, Play, and Child Development. Cambridge University Press. https://doi.org/10.1017/CBO9780511527616

Henao, L., Hui, M., \& Gordon S. (2017). AFRICA 2030: How Africa can achieve sustainable development goals. Version 2. Japan International Cooperation Agency (JICA).

Iji, C., Ogbole, P., \& Uka, N. K. (2014). Effect of Improvised Instructional Materials on Students' Achievement in Geometry at the Upper Basic Education Level in Makurdi Metropolis, Benue State, Nigeria. American Journal of Educational Research, 2(7), 538542.

Kadzera, C. M. (2006). Use of instructional technologies in teacher training colleges in Malawi. Unpublished Thesis. Curriculum and Instruction. Virginia Polytechnic Institute and State University.

Kalina, C. J. (2009). Cognitive and social constructivism: Developing tools for an effective classroom. 130(2).

Kalyan, C. (2020). Attitude towards science and technology in relation to learning, interest, and life experience. UGC Care Journal, 43(3), 64-69 
Kothari, C. (2004). Research Methodology: Methods and Techniques. $2^{\text {nd }}$ Edition, New Age International Publisher, New Delhi.

Liao, S. (2012). The Application of Piaget and Bruner's s cognitive-developmental Theory in Children's Dance and Teaching. International Journal of Arts Education, 7(1), 164-197.

Mabagala, D. L. \& Shukia. R. (2019). Pre-primary Education in Tanzania: Teachers' Knowledge and Instructional Practices in Rural Areas. Huria Journal, 26 (1), 50-65

McMillan, J. H., \& Schumacher, S. (2010). Education research: Evidence-based inquiry. $7^{\text {th }}$ Edition. Virginia Commonwealth University. Pearson.

Msafiri, L. (2017). Strategies for motivating teachers in Tanzanian rural public ordinary secondary schools: A case of Ushetu council in Kahama District. Unpublished Thesis. Arts in Education. The University of Dodoma, Tanzania

Ndihokubwayo, K., \& Habiyaremye, H. T. (2018). African Research Review. International Multi-Disciplinary Journal, 12(3), 38-48. https://doi.org/10.4314/afrrev.v12i3.4

Ndihokubwayo, K., Uwamahoro, J., \& Ndayambaje, I. (2020). Usability of Electronic Instructional Tools in the Physics Classroom. EURASIA Journal of Mathematics, Science and Technology Education, 16(11), 1-10. https://doi.org//10.29333/ejmste/8549

Nizeyimana, G., Nzabalirwa, W., Mukingambeho, G \& Nkiliye, I. (2021). Hindrances to Quality of Basic Education in Rwanda. Rwandan Journal of Education, 5 (1)

Ng'etich, H., \& Chemwei, B. (2015). Availability and Use of Instructional Materials in the Teaching of Conflict and Conflict Resolution in Primary Schools in Nandi North District, Kenya. International Journal of Education and Practice, 3(6), 224-234. https://doi.org/10.18488/journal.61/2015.3.6./61.6.224.234

Nyirahabimana, A. (2019). Instructional resources and learners' academic performance : A case study of boarding schools in Muhanga District. International Journal of Social Sciences, Humanities, and Education, 3(3), 1-16

Ogbu, J. E. (2015). Influences of Inadequate Instructional Materials and Facilities in Teaching and Learning of Electrical/Electronic Technology Education Courses. Journal of Education and Practice, 6(33), 39-46

Okobia, E. O. (2011). Availability and Teachers 'Use of Instructional Materials and Resources in the Implementation of Social Studies in Junior Secondary Schools in Edo 
State, Nigeria. 3(2), 90-97. https://doi.org/10.5539/res.v3n2p90

Olayinka, A. R. B. (2016). Effects of Instructional Materials on Secondary Schools Students' Academic Achievement in Social Studies in Ekiti State, Nigeria. World Journal of Education, 6(1). https://doi.org/10.5430/wje.v6n1p32

Onasanya et al. (2008). Education Performance and Assessment Of Teachers' competence In Instructional Media Technologies in Junior Secondary Schools in Kwara Estate. Horden Publishers Ltd.

Rwanda Education Board. (2015). Mathematics syllabus for upper primary P4 - 6. Kigali

Ukobizaba, F., Ndihokubwayo, K., Mukuka, A., \& Uwamahoro, J. (2019). Insights of teachers and students on mathematics teaching and learning in selected Rwandan secondary schools. African Journal of Educational Studies in Mathematics and Sciences, 15(2), 93-107. https://dx.doi.org/10.4314/ajesms.v15i2.8

Umugiraneza, O., Bansilal, S., \& North, D. (2018). Exploring teachers' use of technology in teaching and learning mathematics in KwaZulu-Natal schools. Pythagoras, 39(1), 1-13. https://doi.org/10.4102/pythagoras.v39i1.342

\section{Appendices}

\section{Appendix I: Classroom observation checklist}

Utilization of instructional materials in mathematics classroom

\begin{tabular}{|l|l|l|}
\hline Statements check list & Yes & No \\
\hline Are there any instructional materials in the classroom & & \\
\hline In class, there are concrete instructional materials? & & \\
\hline $\begin{array}{l}\text { Are printed instructional materials available in the } \\
\text { classroom? }\end{array}$ & & \\
\hline $\begin{array}{l}\text { Are the instructional materials adequate and appropriate } \\
\text { for the learners? }\end{array}$ & & \\
\hline $\begin{array}{l}\text { Does the teacher use instructional materials during } \\
\text { lesson delivery? }\end{array}$ & & \\
\hline
\end{tabular}




\begin{tabular}{|l|l|l|}
\hline $\begin{array}{l}\text { Does the teacher give learners time to interact with the } \\
\text { instructional materials during the lesson? }\end{array}$ & & \\
\hline Are there any audio-visual materials in the classroom? & & \\
\hline $\begin{array}{l}\text { Were the available instructional materials used } \\
\text { effectively? (Bringing the material that can be seen clearly } \\
\text { by every student, explaining to students why, how, where, and } \\
\text { when it will be used, allowing students to interact and use it } \\
\text { themselves guided by the teacher). }\end{array}$ & & \\
\hline
\end{tabular}

\section{Any other observation}

\section{Thank you for your participation}

\section{Appendix II: Semi-structured interview}

\section{Utilization and types of available materials.}

1. Do you use instructional materials?

2. Do you have instructional materials in the classroom?

3. Which types do you have in the classroom?

4. What are the most available instructional materials in the classroom?

5. How do you use instructional materials that you have?

6. Comparison of teaching lessons with materials and without materials.

7. Do you use audio-visual materials in teaching?

8. What are the source of instructional materials you have?

9. How about getting materials that are not available in the surrounding?

10. Recommendations.

Thank you for your cooperation 